\title{
Assessment of Microbiological Contamination of Fresh, Minimally Processed, and Ready-to-Eat Lettuces (Lactuca sativa), Rio de Janeiro State, Brazil
}

\author{
Marcelo L. L. Brandão, Davi O. Almeida, Fernanda C. P. Bispo, Silvia M. L. Bricio, Victor A. Marin, and Marize P. Miagostovich
}

\begin{abstract}
This study aimed to assess the microbiological contamination of lettuces commercialized in Rio de Janeiro, Brazil, in order to investigate detection of norovirus genogroup II (NoV GII), Salmonella spp., total and fecal coliforms, such as Escherichia coli. For NoV detection samples were processed using the adsorption-elution concentration method associated to real-time quantitative polymerase chain reaction (qPCR). A total of 90 samples of lettuce including 30 whole fresh lettuces, 30 minimally processed (MP) lettuces, and 30 raw ready-to-eat (RTE) lettuce salads were randomly collected from different supermarkets (fresh and MP lettuce samples), food services, and self-service restaurants (RTE lettuce salads), all located in Rio de Janeiro, Brazil, from October 2010 to December 2011. NoV GII was not detected and PP7 bacteriophage used as internal control process (ICP) was recovered in $40.0 \%, 86.7 \%$, and $76.7 \%$ of those samples, respectively. Salmonella spp. was not detected although fecal contamination has been observed by fecal coliform concentrations higher than $10^{2}$ most probable number/g. E. coli was detected in 70.0\%, 6.7\%, and 30.0\% of fresh, MP, and RTE samples, respectively. This study highlights the need to improve hygiene procedures at all stages of vegetable production and to show PP7 bacteriophage as an ICP for recovering RNA viruses' methods from MP and RTE lettuce samples, encouraging the evaluation of new protocols that facilitate the establishment of methodologies for NoV detection in a greater number of food microbiology laboratories.
\end{abstract}

Keywords: bacterial contamination, internal control, lettuce, norovirus, RT-PCR

Practical Application: The PP7 bacteriophage can be used as an internal control process in methods for recovering RNA viruses from minimally processed and ready-to-eat lettuce samples.

\section{Introduction}

Leafy green vegetables are important components of a healthy diet, providing important vitamins, minerals, and phyto-nutrients (Mercanoglu and Halkman 2011). Because of these potential benefits, governments around the world have been promoting the consumption of fresh vegetables and their minimally processed (MP) products to prevent diseases (FAO and WHO 2008a). However, there has been an increasing recognition of foodborne disease outbreaks linked to the consumption of ready-to-eat (RTE) vegetables (FAO and WHO 2008b; Berger and others 2010). Food and Agriculture Organization of the United Nations (FAO) and the World Health Organization (WHO) convened an Expert Meeting to discuss how to address adequately the scientific advice on microbiological hazards associated with fresh produce. Leafy green vegetables were identified as the commodity group of highest concern from a microbiological safety perspective. Norovirus (NoV), Escherichia coli O157:H7, and Salmonella spp. were included among

MS 20131749 Submitted 11/24/2013, Accepted 3/10/2014. Authors Brandão Almeida, Bispo, Bricio, and Marin are with Laboratory of Products, Microbiology Dept, National Inst. of Quality Control in Health, Oswaldo Cruz Foundation, Av. Brasil, 4365, Manguinhos, Rio de Janeiro - RJ, Brazil, CEP 21040-900. Author Miagostovich is with Laboratory of Comparative Virology, Oswaldo Cruz Inst, Oswaldo Cruz Foundation, Av. Brasil, 4365, Manguinhos, Rio de Janeiro-RJ, Brazil, CEP 21040 -900. Direct inquiries to author Brandão (E-mail: marcelollb_8@hotmail.com). the more common pathogenic microorganisms that can be transmitted to humans by consumption of these products (FAO and WHO 2008a).

Leafy green vegetables are produced in diverse and complex ways, and can be exposed to microbial contamination at various stages during the production, as preharvest, harvest, packing, processing, storage, or during distribution. Preharvest contamination can occur directly or indirectly via animals, water, soil, dirty equipment, and human manipulating. However, the fecal contamination of the irrigation water and the use of manure or compost fertilizer to fields are the most important vials of contamination (FAO and WHO 2008a; Oliveira and others 2010). In Brazil, from 2000 to 2011; 7234 foodborne outbreaks were reported, of which the leafy green vegetables have been implicated as a vehicle of contamination in $96(1.33 \%)$. The most common etiologic agent isolated in the foodborne outbreaks is Salmonella spp. that were identified in 1660 (22.95\%) outbreaks. E. coli appears in the 4th position, being responsible for 411 outbreaks (5.68\%) (Brasil 2013).

The NoV genus belongs to the Caliciviridae family and is divided into 5 genogroups $(\mathrm{G})$, which GI, II, and IV are known to infect humans (Zheng and others 2006). NoV is one of the major causes of acute gastroenteritis worldwide and is responsible for up to 1.1 million hospitalizations with an estimated mortality rate of approximately 218.000 deaths per year (Patel and others 2008). 
NoV GII has being the most prevalent in cases of foodborne infections (Patel and others 2009). In Brazil, GII.4 strain is the most prevalent NoV genotype circulating and responsible for the major of NoV foodborne outbreaks (Ferreira and others 2008; Barreira and others 2010; Fioretti and others 2011).

Many well-documented foodborne outbreaks due to NoV have been examined in epidemiological investigations (FAO and WHO $2008 \mathrm{~b}$ ). However, the direct detection of NoV in the implicated foods is generally unsuccessful (Scherer and others 2010). To improve microbiological monitoring of food quality and to assess the true role of food in viral transmission, standardized methods need to be developed for use in reference laboratories and for monitoring foodstuffs (Croci and others 2008). New approaches have focused on virus extraction, concentration and detection by using polymerase chain reaction (PCR) technology in order to improve sensitivity (Morales-Rayas and others 2010; Sánchez and others 2012).

The current study aims to asses NoV GII and bacteriological contamination by Salmonella spp., total and fecal coliform (and the E. coli identification) levels in samples of fresh, MP, and RTE lettuces commercialized in the State of Rio de Janeiro, Brazil. The bacteriophage PP7 was also evaluated as internal control process (ICP) of viral concentration methodology, since it is regarded as a suitable surrogate for human enteric viruses from water samples (Rajal and others 2007a, 2007b).

\section{Materials and Methods}

\section{Viruses}

NoV (Hawaii virus) GII.1 strain prototype and PP7 bacteriophage (ATCC 15692-B2) were used for constructing the standard curve (SC) of the quantitative assays. A $10 \%(\mathrm{w} / \mathrm{v})$ positive fecal suspension containing NoV GII from the Regional Reference Gastroenteritis Laboratory collection, Oswaldo Cruz Institute, Rio de Janeiro-RJ, Brazil, and the PP7 bacteriophage were used for spiking experiments. Titers of both viruses were established by real time PCR based on SC, represented by the absolute number of genome copies (gc) $/ \mu \mathrm{L}$ (Yin and others 2001).

\section{Samples of lettuce}

A total of 90 samples of lettuce including 30 whole fresh lettuces, $30 \mathrm{MP}$ lettuces, and 30 raw RTE lettuce salads were randomly collected from different supermarkets (fresh and MP lettuce samples), food services, and self-service restaurants (RTE lettuce salads), all located in Rio de Janeiro, Brazil, from October 2010 to December 2011. The MP are defined as lettuce samples previously washed and soaked with appropriated sanitizing chemical and sold in disposable plastic food containers, being those procedures performed by producers. Products were transported individually under refrigeration $\left(4\right.$ to $\left.8^{\circ} \mathrm{C}\right)$ to the laboratory.

\section{Viral concentration method}

An adsorption-elution concentration method using negatively charged membranes was performed according to the protocol described by Fumian and others (2009) with one modification: the centrifugation step was removed and the samples were weighed $(25 \mathrm{~g})$ in sterile Whirl-Pak ${ }^{\circledR}$ Stomacher filter bags (Nasco, Fort Atkinson, Wis., U.S.A.) and homogenized in a Stomacher ${ }^{\circledR}$ apparatus (Seward, Fisher Scientific, Sainte-Foy, Quebec, Canada) as described by other authors (Scherer and others 2010; Stals and others 2011; Sánchez and others 2012). The rinse fluid left in the filter compartment of the bag was used to perform the analysis.
Each commercialized lettuce product was inoculated with $50 \mu \mathrm{L}$ of PP7 bacteriophage viral suspension $\left(\approx 3 \times 10^{5} \mathrm{gc}\right)$ as an ICP.

\section{RNA extraction, cDNA synthesis, virus detection, and quantification methods}

Viral RNA was extracted from $140 \mu \mathrm{L}$ of the $2 \mathrm{~mL}$ final eluate using QIAamp ${ }^{\circledR}$ viral RNA mini kit (Qiagen ${ }^{\circledR}$, Valencia, Calif., U.S.A.) in accordance with the manufacturer's instructions to obtain a final volume of $60 \mu \mathrm{L}$. The High-Capacity kit (Applied Biosystems, Calif., U.S.A.) was used for cDNA synthesis. In each reaction, $12.5 \mu \mathrm{L}$ of viral RNA extract was added to a 12.5 $\mu \mathrm{L}$ of RT reaction mixture containing: $1 \times$ buffer, $8 \mathrm{mmol} / \mathrm{L}$ of each dNTP, $62.5 \mathrm{U}$ of MultiScribe ${ }^{\mathrm{TM}}$ reverse transcriptase, and $2 \times$ random primers. The reverse transcription conditions were performed as such: $10 \mathrm{~min}$ at $25^{\circ} \mathrm{C}, 2 \mathrm{~h}$ at $37^{\circ} \mathrm{C}$, and $5 \mathrm{~min}$ at $85{ }^{\circ} \mathrm{C}$. For each reaction set-up, negative (DNA/RNA free water-BioBasic, Ontario, Canada) and positive (NoV GII or PP7 bacteriophage) controls were included. With the intention to investigate the presence of inhibitors in samples, cDNA was also prepared using a 1:10 RNA dilution.

Nov GII and PP7 bacteriophage detection was conducted using a TaqMan ${ }^{\circledR}$ technology of real-time quantitative polymerase chain reaction (qPCR) according to protocols described previously (Kageyama and others 2003; Fumian and others 2010). Primers and probes are shown in Table 1. Reactions were performed in duplicate using the ABI 7500 real-time PCR system (Applied Biosystems ${ }^{\circledR}$ ) according to the manufacturer's instructions. The generation of plasmids and the construction of the SC were performed as described previously (Fumian and others 2009, 2010). The SC was created using tenfold serial dilutions of $\mathrm{pCR}{ }^{\circledR} 2.1-\mathrm{TOPO}^{\circledR}$ vectors (Invitrogen, Van Allen Way Carlsbad, Calif., U.S.A.) containing either the ORF1/ORF2 overlap region of the NoV genome $\left(5.0 \times 10^{6}\right.$ to $\left.5.0 \times 10^{0}\right)$ or the PP7 replicase gene $\left(1.0 \times 10^{7}\right.$ to $\left.1.0 \times 10^{1}\right)$. Seminested PCR was also performed to detect $\mathrm{NoV}$ GII with primers JV13I, JV12Y, and NoroII-R (inner primer is specific for GII genotypes) which target the viral RNA-dependent RNA polymerase gene (Boxman and others 2006). All procedures comprised negative (DNA/RNA free water) and positive (NoV GII and PP7 bacteriophage) controls to avoid false results.

\section{NoV GII and PP7 bacteriophage efficiency recovery}

Recovery efficiency of both NoV GII and PP7 bacteriophage was evaluated by experimental assays of artificial contamination. Briefly, 3 aliquots of $25 \mathrm{~g}$ of whole fresh lettuce samples were seeded by direct application of $200 \mu \mathrm{L}$ of NoV GII fecal suspension and PP7 bacteriophage particles suspension onto food surface. After $30 \mathrm{~min}$ in a laminar flow hood, in order to facilitate viruses attachment, samples were analyzed according to the methodologies above described. Unspiked samples were processed as negative controls. The titers of NoV GII in the fecal suspension and PP7 bacteriophage particle suspensions used for experiments were established by real time PCR based on SC that are represented by the absolute number of $\mathrm{gc} / \mu \mathrm{L}$. Part of the NoV GII fecal suspension and PP7 bacteriophage suspension were applied to RNA extraction and quantification together with the contaminated aliquots. For each type of virus and negative controls, 3 independently experiments were carried out using phosphate saline buffer (PBS) as elution solution.

Recovery of NoV GII and PP7 bacteriophage were both quantitatively and qualitatively analyzed as described by Stals and others (2011). Quantitative analysis ("recovery efficiency") was 
Table 1-Primers and probes used for real-time quantitative PCRs and nested PCR performed in this study.

\begin{tabular}{|c|c|c|c|c|}
\hline Molecular method & Virus & Primer/Probe & Sequence $\left(5^{\prime} \rightarrow 3^{\prime}\right)$ & Location \\
\hline \multirow[t]{6}{*}{ Real-time quantitative PCR } & NoV GII & $\mathrm{COG} 2 \mathrm{~F}$ & CARGARBCNATGTTYAGRTGGATGAG & $5003^{\mathrm{a}}$ \\
\hline & & COG2R & TCGACGCCATCTTCATTCACA & 5100 \\
\hline & & RING2-TP & FAM_TGGGAGGGCGATCGCAATCT_TAMRA & 5048 \\
\hline & PP7 & $247 \mathrm{f}$ & GTTATGAACCAATGTGGCCGTTAT & $247^{\mathrm{b}}$ \\
\hline & & $320 \mathrm{r}$ & CGGGATGCCTCTGAAAAAAG & 320 \\
\hline & & 274 probe & FAM_TCGGTGGTCAACGAGGAACTGGAAC-TAMRA & 274 \\
\hline \multirow[t]{3}{*}{ Nested PCR } & NoV GII & JV13I & TCATCATCACCATAGAAIGAG & $4585^{\mathrm{c}}$ \\
\hline & & JV12Y & ATACCACTATGATGCAGAYTA & 4279 \\
\hline & & NoroII-R & AGCCAGTGGGCGATGGAATTC & 4495 \\
\hline
\end{tabular}

Degenerate primers and probes are as follows: $\mathrm{Y}, \mathrm{C}$, or T; R, A, or G; B, not A; N, any. W, A, or T; K, G, or T; S, G, or C.

${ }^{a}$ Corresponding nucleotide position in PP7 bacteriophage (accession nr. NC_001628).

${ }^{\mathrm{b}}$ Corresponding nucleotide position in human NoV (accession nr. AF145896).

${ }^{c}$ Corresponding nucleotide position in human NoV (accession nr. M87661).

Table 2-Evaluation of recovery efficiency of PP7 bacteriophage and NoV GII from artificially contaminated whole fresh lettuce samples.

\begin{tabular}{|c|c|c|c|}
\hline Viruses & $\begin{array}{l}\text { Nr. of inoculated } \\
\text { copies }(\text { mean } \pm \\
\left.\operatorname{SD}^{\mathrm{a}}\right)\left(\times 10^{6}\right)\end{array}$ & $\begin{array}{l}\text { Recovery copies } \\
(\text { mean } \pm \text { SD }) \\
\left(\times 10^{6}\right)\end{array}$ & $\begin{array}{c}\text { Recovery } \\
\text { efficiency (mean } \\
\pm \text { SD) (recovery } \\
\text { success rate) }\end{array}$ \\
\hline & 934 & 25.98 & 0.6 \\
\hline NoV GII & 16.69 & $0.036 \pm 0.029$ & $0.24 \pm 0.20(6 / 9)$ \\
\hline
\end{tabular}

${ }^{\text {a Standard deviation; }}{ }^{\mathrm{b}}(\#$ genomic copies recovered $\times 100) / \#$ genomic copies inoculated in $25 \mathrm{~g}$ of lettuce sample; ${ }^{\mathrm{c}}$ \# Positive real-time PCR reactions/ \# performed real-time PCR reactions.

calculated by comparing the mean of NoV GII or PP7 bacteriophage gc recovered with the mean of gc inoculated. Qualitative analysis ("recovery success rate") of NoV GII or PP7 bacteriophage recovery was performed by comparing the number of positive real-time PCR signals with the total number of reactions.

\section{Bacteriological analysis}

Microbiological assays using culture methods were performed according to standard methodologies described by the Food and Drug Administration's Bacteriological Analytical Manual online. Counts of total and fecal coliforms were carried out by a multiple-tube fermentation technique (Feng and others 2002) and Salmonella spp. detection was performed as described by Andrews and Hammack (2011).

\section{Statistical analyses}

Prevalence, mean values, and standard deviations (SD) of all variables were calculated. A nonparametric Kruskal-Wallis test (KW test) followed by Dunn's method of comparison was applied to verify the difference among the values of total and fecal coliforms among the fresh, MP, and RTE lettuce samples. The latter was also used to compare if recovery success rate of PP7 bacteriophage was different amid samples. Binomial test ( 2 proportions) was used to determine the proportion of E. coli in distinct types of samples. Differences were considered statistically significant when $P$-values were lower than 0.05. All statistical calculations were performed using Biostat 5.0 (Universidade Federal do Pará, Brazil, 2007).

\section{Results}

To evaluate the recovery of NoV GII and PP7 bacteriophage using the adsorption-elution concentration method with negatively charged membranes, identical sized lettuce samples were artificially spiked with both viruses. According to Table 2, the PP7 bacteriophage was detected in all contaminated samples showing a recovery efficiency that ranged from $0.12 \%$ to $2.08 \%$ with a mean of $0.63 \% \pm 0.43 \%$. NoV GII was detected in 6 out of 9 contaminated samples $(66.7 \%)$ showing a recovery efficiency that ranged from $0.06 \%$ to $0.67 \%$, with an average of $0.24 \% \pm 0.20 \%$ (Table 2). The viruses were not detected in negative controls.

The investigation of microbiological contamination in 90 lettuce samples obtained in Rio de Janeiro did not reveal the presence of NoV GII by any of the methodologies (qPCR and nested PCR). Concerning the use of PP7 as ICP, it was observed a recovery of $67.8 \%$ with a significant difference (KW test; $P=0.011$ ) according to the type of lettuce tested (Table 3). By using Dunn's comparison method, no significant difference was observed between RTE salads and the others $(P>0.05)$. On the other hand, when comparing whole fresh and MP lettuce samples, a significant difference was noticed $(P<0.05)$, indicating that the method showed a lower performance for ICP recovery when applied to whole fresh lettuce samples.

Salmonella spp. was not detected in any of the 90 commercialized lettuce samples analyzed. Enumeration of total and fecal coliforms in lettuce samples were summarized in Table 4. Mean values of total coliforms in whole fresh samples were significantly higher $(P<0.05)$, while MP and RTE samples did not show a significant difference $(P>0.05)$. Mean fecal coliforms counts ranged from $<3.0$ to $1.5 \times 10^{3},<3.0$ to $1.5 \times 10^{2}$, and $<3.0$ to $>1.1 \times 10^{4}$ most probable number $(\mathrm{MPN}) / \mathrm{g}$ in whole fresh, MP, and RTE lettuce samples, respectively. Difference among the average of fecal coliform count in MP samples was significantly lower than in whole fresh and RTE samples $(P<0.05)$. In turn, whole fresh and RTE lettuce samples did not present a significant difference $(P>0.05)$. E. coli was detected in $21(70.0 \%), 2$ $(6.7 \%)$, and 9 samples $(30.0 \%)$ of fresh, MP, and RTE lettuces, respectively. The prevalence of $E$. coli was significantly different according to the type of lettuce tested $(P<0.001)$.

\section{Discussion}

The advances on molecular methods for detection and quantification of $\mathrm{NoV}$ along with food security policies established in various countries from the last 3 decades resulted in a remarkable number of protocols for recovering those viruses from food (Croci and others 2008; Fumian and others 2009; Morales-Rayas and others 2010; Scherer and others 2010; Sánchez and others 2012; Corrêa and Miagostovich 2013). The difficulty of recovering a small number of particles associated with the interference of different food matrices has been circumvented by the use of more sensitive detection methods such as real-time PCR and the use of 
Table 3-PP7 bacteriophage recovery by qPCR of spiked commercialized lettuce product samples.

\begin{tabular}{|c|c|c|c|c|c|c|}
\hline Type of lettuce & $\begin{array}{c}\text { Nr. of inoculated } \\
\text { copies }\left(\text { mean } \pm S^{a}\right) \\
\left(\times 10^{2}\right)\end{array}$ & $\begin{array}{c}\text { Recovery copies } \\
(\text { mean } \pm \mathrm{SD}) \\
\left(\times 10^{2}\right)\end{array}$ & $\begin{array}{c}\text { Recovery } \\
\text { efficiency } \\
(\text { mean } \pm \mathrm{SD})\end{array}$ & $\begin{array}{l}\text { Minimum } \\
\text { recovery } \\
\text { efficiency }\end{array}$ & $\begin{array}{l}\text { Maximum } \\
\text { recovery } \\
\text { efficiency }\end{array}$ & $\begin{array}{c}\text { Recovery } \\
\text { success rate }^{c}(\%)\end{array}$ \\
\hline Fresh & $1916.53 \pm 756.14$ & $31.51 \pm 50.42$ & $2.01 \pm 3.29 \%$ & $0.01 \%$ & $10.82 \%$ & $12 / 30(40.0 \%)$ \\
\hline $\mathrm{MP}^{\mathrm{d}}$ & $1611.80 \pm 728.08$ & $9.97 \pm 11.18$ & $0.67 \pm 0.88 \%$ & $0.01 \%$ & $4.36 \%$ & $26 / 30(86.7 \%)$ \\
\hline RTE $^{\mathrm{e}}$ salads & $6320.35 \pm 5822.97$ & $16.80 \pm 44.91$ & $0.49 \pm 0.69 \%$ & $0.001 \%$ & $2.39 \%$ & $23 / 30(76.7 \%)$ \\
\hline
\end{tabular}

${ }^{a}$ Standard deviation; ${ }^{b}$ (\# genomic copies recovered from concentrate $\times 100$ )/\# genomic copies inoculated in $25 \mathrm{~g}$ of lettuce sample; ${ }^{c} \#$ Positive real-time PCR reactions/ \# performed real-time PCR reactions; ${ }^{\mathrm{d}}$ minimally processed; ${ }^{\mathrm{e}}$ ready-to-eat.

Table 4-Total and fecal coliforms in lettuce samples.

\begin{tabular}{|c|c|c|c|c|c|c|c|}
\hline \multirow[b]{2}{*}{ Microorganisms } & \multirow[b]{2}{*}{ Type of sample } & \multicolumn{5}{|c|}{ Microbial population ${ }^{a}(\%$ positive samples) } & \multirow[b]{2}{*}{ Nr. of positive samples $(\%)^{b}$} \\
\hline & & $<3.0$ & 3.1 to 99 & 100 to 999 & 1000 to 11000 & $>11000$ & \\
\hline \multirow[t]{3}{*}{ Total coliforms } & Fresh & 0 & 0 & 0 & $15(50.0)$ & $15(50.0)$ & $30(100.0)$ \\
\hline & $\mathrm{MP}^{\mathrm{c}}$ & 0 & $6(20.0)$ & $9(30.0)$ & $9(30.0)$ & $6(20.0)$ & $30(100.0)$ \\
\hline & RTE $^{\mathrm{d}}$ salads & 0 & $2(6.7)$ & $6(20.0)$ & $12(40.0)$ & $10(33.3)$ & $30(100.0)$ \\
\hline \multirow{3}{*}{ Fecal coliforms } & Fresh & $8(26.7)$ & $18(60.0)$ & $3(10.0)$ & $1(3.3)$ & 0 & $22(73.3)$ \\
\hline & MP & $26(86.7)$ & $3(10.0)$ & $1(3.3)$ & 0 & 0 & $4(13.3)$ \\
\hline & RTE salads & $8(26.7)$ & $16(53.4)$ & $4(13.3)$ & $1(3.3)$ & $1(3.3)$ & $22(73.3)$ \\
\hline
\end{tabular}

${ }^{\mathrm{a}}$ Most probable number/g; ${ }^{\mathrm{b}}$ (\# of positive samples/ \# of samples) $\times 100 ;{ }^{\mathrm{c}}$ minimally processed; ${ }^{\mathrm{d}}$ ready-to-eat.

ICP allowing higher reliability of the results (Kageyama and others 2003; Mattison and others 2009; Stals and others 2011).

This study focused on PP7 bacteriophage as ICP rather than other viruses as Murine Norovirus 1 (MNV-1) (Stals and others 2011; Sánchez and others 2012; Corrêa and Miagostovich 2013), feline calicivirus (FCV) (Mattison and others 2009), MS2 phage (Scherer and others 2010), or Mengo virus (Uhrbrand and others 2010) since PP7 propagation is more accessible to food microbiology laboratories than cell cultures used to produce stocks of those viruses (Rajal and others 2007b). PP7 bacteriophage has also been successfully used in processes of concentrating viruses in aquatic matrices and have been chosen due to its similarity both by its size $(25 \mathrm{~nm})$ and its physicochemical properties to poliovirus, simulating the worst scenario for viral filtration (Rajal and others 2007b; Fumian and others 2010). Comparing with these others viruses used as IPC, Mattison and others (2010) detected the FCV in $83 \%$ of the RTE packaged leafy greens samples analyzed. This result was similar to our findings, since the PP7 bacteriophage was detected in $86.7 \%$ and $76.7 \%$ of MP and RTE lettuce samples, respectively. Scherer and others (2010) using MS2 phage as ICP reported a lower recovery rate, ranging from $6 \%$ to $10 \%$ for samples cut fruit and vegetables. On the other hand, Sánchez and others (2012) used the MNV-1 as ICP for in samples of fresh fresh-cut vegetables and detected the MNV-1 in all spiked samples.

The success of the initial experiments conducted to evaluate the PP7 recovery from the filtration methodology (100.0\%) determined its use as ICP in the samples investigated. However, PP7 bacteriophage was not detected in all commercialized spiked lettuce samples, indicating the presence of inhibitors in the lettuce samples analyzed (Table 3). PP7 bacteriophage showed a higher success rate in MP and RTE lettuce samples compared to whole fresh lettuce samples, suggesting that the act of washing lettuces reduces the solids and the concentration of inhibitory substances onto matrix surfaces. Furthermore, PP7 bacteriophage adsorption to solids can occur, lowering the overall recovery (Rajal and others 2007a) as well as the clogging of filters due to a large quantity of debris that may be present in the samples, especially whole fresh ones, reducing the recovery rate (Victoria and others 2010). The effect of different food matrices on the viral quantification in food products has been investigated by some authors and the results vary according to the type of food (Stals and others 2011). The nucleic acid dilution described as a common strategy used for environmental samples (Fumian and others 2010; Victoria and others 2010; Prado and others 2011) for overcoming inhibition of PCR amplifications was used in this study (data not shown) but it was not efficient enough to avoid the inhibitions observed, including recovering of NoV GII. One hypothesis raised to explain the low percentage of NoV GII recovery obtained is the presence of free RNA and defective viral particles in fecal suspension used to spike experiments. Those can be detected when subjected to nucleic acid extraction but are more susceptible to elimination during the concentration step. This leads to an underestimated calculation of the NoV GII recovery efficiency due to the heterogeneity of the fecal suspension (Sánchez and others 2012). Other methodologies vary greatly in the percentage of $\mathrm{NoV}$ recovery from different types of lettuce samples, ranging from $0.005 \%$ to $99 \%$ (Fumian and others 2009; Morales-Rayas and others 2010; Scherer and others 2010; Stals and others 2011; Sánchez and others 2012). The NoV detection and ICP results were similar to those reported by other researchers (De Giusti and others 2010; Scherer and others 2010) and stress the need to carry out further studies to establish the use of PP7 bacteriophage as ICP.

Concerning bacteriological results, the absence of Salmonella spp. in lettuce concurs with results of previous studies carried out with other types of Brazilian vegetables (Abreu and others 2010; Santos and others 2010), although Salmonella spp. is still the most common pathogens identified in outbreaks throughout the country (Brasil 2013). Studies reporting the presence of this pathogen in whole fresh and MP vegetables (Fröder and others 2007; Tresseler and others 2009) have been published but, in general, besides the outbreaks being associated with the consumption of contaminated vegetables it is not possible to identify the pathogen itself implicated in the outbreak (Brasil 2013). Total coliforms higher than $10^{2} \mathrm{MPN} / \mathrm{g}$ is commonly reported in those kind of products (Fröder and others 2007; Silva and others 2007; Santos and others 2010), since coliform bacteria occurs naturally on microflora of vegetables (FAO/WHO 2008a). Fecal coliforms detected in RTE lettuce samples reflects unsatisfactory hygienic condition 
and did not meet the Brazilian Standards (Brasil 2001) that advocates a maximum of $10^{2} / \mathrm{g}$ for fecal coliforms for RTE and MP vegetables. Similar results to those were reported in other studies on fresh lettuce (Loncarevic and others 2005; Fröder and others 2007; Abreu and others 2010; Santos and others 2010). The presence of E. coli in whole fresh lettuce could be due to inadequate hygienic practices during preharvest or sporadic contamination through irrigation water (Oliveira and others 2010). E. coli prevalence in fresh lettuce found in this study was superior to that reported by others (Loncarevic and others 2005; Oliveira and others 2010). In other studies using MP and RTE vegetables commercialized in Brazil, the occurrence of E. coli ranged from $28.6 \%$ to $32.9 \%$ (Silva and others 2007; Santos and others 2010). As fecal coliforms other than E. coli, such as Enterobacter and Klebsiella, are normally part of native microflora of fresh vegetables, $E$. coli is considered a better indicator of contamination (Loncarevic and others 2005).

The results of microbiological analysis of RTE lettuce served in restaurants indicate deficiencies in hygiene procedures applied during the production line and/or failures in the storage process of these products. The presence of fecal coliforms as well as E. coli, suggest that the sanitization of the product was unsuccessful.

\section{Conclusion}

Concluding from the results obtained, it seems clear that measures to improve all stages of crop production including irrigation and manipulation of the prepared product should be encouraged, as well as the evaluation of viral detection protocols using new approaches such as PP7 bacteriophage as ICP.

\section{Acknowledgments}

The authors thank to Dr. Christopher Gallimore (Enteric Virus Unit, Virus Reference Department, Centre for Infections, Health Protection Agency, Colindale, London, United Kingdom), and to Dr. Verónica Rajal (Salta University, Argentina) for kindly providied NoV (Hawaii virus) GII.1 strain prototype and PP7 bacteriophage (ATCC 15692-B2), respectively. This work was supported by CNPq-Edital MCT/CNPq Nr. 019/2010. D. Almeida, F. Bispo, and M Miagostovich are CNPq's fellowship researchers. This study is under the scope of the activities of Fiocruz as a collaborating center of PAHO/WHO of Public and Environmental Health.

\section{Author Contributions}

M. Brandão carried out the experiments and drafted the manuscript. D. Almeida carried out the experiments and revised the manuscript. F. Bispo carried out the experiments. S. Bricio revised the manuscript. V. Marin revised the manuscript. M. Miagostovich revised the manuscript.

\section{References}

Abreu IMO, Junqueira AMR, Peixoto JR, Oliveira SA. 2010. Qualidade microbiológica e produtividade de alface sob adubação química e orgânica. Ciência e Tecnologia de Alimentos 30(Supl.1):108-18

Andrews WH, Hammack TS. 2011. Salmonella. In: Bacteriological analytical manual, Chap. 5. [S.1]; Food and Drug Administration. Available from: http://www.fda.gov/Food/FoodScienceResearch/LaboratoryMethods/ucm070149.htm. Accessed 2013 November 12.

Barreira DMPG, Ferreira MSR, Fumian TM, Checon R, de Sadovsky ADI, Leite J P G, Miagostovich MP, Spano LC. 2010. Viral load and genotypes of noroviruses in symptomatic and asymptomatic children in Southeastern Brazil. J Clin Virol 47(1):60-4.

Berger CN, Sodha SV, Shaw RK, Griffin PM, Pink D, Hand P, Frankel G. 2010. Fresh fruit and vegetables as vehicles for the transmission of human pathogens. Environ Microbiol 12(9):2385-97.

Boxman IL, Tilburg JJ, Te loeke NA, Vennema H, Jonker K, De boer E, Koopmans M. 2006 Detection of noroviruses in shellfish in the Netherlands. Int J Food Microbiol 108(3):391-6.
Brasil. 2013. Ministério da Saúde, Agência Nacional de Vigilância Sanitária. Unidade Técnica de Doenças de Veiculação Hídrica e Alimentar - UHA, Coordenação Geral de Doenças Transmissíveis - CGDT, Secretaria de Vigilância em Saúde - SVS. Dados Epidemiológicos - DTA período de a 2011. Available from: http://portal.saude. gov.br/portal/saude/profissional/area.cfm?id_area=1550. Accessed 2013 November 12.

Brasil. 2001. Ministério da Saúde, Agência Nacional de Vigilância Sanitária. 26 January. RDC no. 12 .

Corrêa AA, Miagostovich MP. 2013. Optimization of an adsorption-elution method with a negatively charged membrane to recover Norovirus from lettuce. Food Environ Virol 5(3):144-9.

Croci L, Dubois E, Cook N, De Medici D, Schultz AC, China B, Rutjes SA, Hoorfar J, Van der poel WHM. 2008. Current methods for extraction and concentration of enteric viruses from fresh fruit and vegetables: towards international standards. Food Anal Methods 1(2):73-84.

De Giusti M, Aurigemma C, Marinelli L, Tufi D, Medici D, Pasquale S, Vito C, Boccia A. 2010. The evaluation of the microbial safety of fresh ready-to-eat vegetables produced by different technologies in Italy. J Appl Microbiol 109(3):996-1006.

FAO/WHO [Food and Agricultural Organization of the United Nations/World Health Organization]. 2008a. Microbiological hazards in fresh leafy vegetables and herbs: meeting report. Microbiological Risk Assessment Series Nr. 14. Rome. 151 pp. Available from: http://www.who.int/foodsafety/publications/micro/mra_fruitveges/en. Accessed 2013 November 12.

FAO/WHO [Food and Agricultural Organization of the United Nations/World Health Organization]. 2008b. Viruses in food: scientific advice to support risk management activities: meeting report. Microbiological Risk Assessment Series Nr. 13. Rome. 58 pp. Available from: http://www.who.int/foodsafety/publications/micro/mra13/en. Accessed 2013 Novembe 12.

Feng P, Weagant SD, Grant MA. Enumeration of Escherichia coli and the Coliform Bacteria. 2002. In: Bacteriological analytical manual, Chap. 4. [S.1]; FDA. Available from: http://www.fda.gov/Food/FoodScienceResearch/LaboratoryMethods/ucm064948.htm. Accessed 2013 November 12.

Ferreira MSR, Xavier MPTP, Fumian TM, Victoria M, Oliveira SA, Pena LHA, Leite JPG, Miagostovich MP. 2008. Acute gastroenteritis cases associated with noroviruses infection in the State of Rio de Janeiro. J Medical Virol 80(2):338-44.

Fioretti JM, Ferreira MSR, Victoria M, Vieira CB, Xavier MPTP, Leite JPG, Miagostovich MP. 2011. Genetic diversity of norovirus in Brazil. Mem Inst Oswaldo Cruz 106(8):942-7.

Fröder H, Martins CG, Souza KLO, Landgraf M, Franco BDGM, Destro MT. 2007. Minimally processed vegetable salads: microbial quality evaluation. J Food Prot 70(5):1277-80.

Fumian TM, Leite JPG, Marin VA, Miagostovich MP. 2009. A rapid procedure for detecting noroviruses from cheese and fresh lettuce. J Virol Methods 155(1):39-43.

Fumian TM, Leite JPG, Castello AA, Gaggero A, Caillou MSL, Miagostovich MP. 2010 Detection of rotavirus A in sewage sample using multiplex qPCR and an evaluation of the ultracentrifugation and adsorption-elution methods for virus concentration. J Virol Methods $170(1-2): 42-6$.

Kageyama T, Kojima S, Shinohara M, Uchida K, Fukushi S, Hoshino FB, Takeda N, Katayama K. 2003. Broadly reactive and highly sensitive assay for Norwalk-like viruses based on real-time quantitative reverse transcription-PCR. J Clin Microbiol 41(4):1548-57.

Loncarevic S, Johannessen GS, Rorvik LM. 2005. Bacteriological quality of organically grown leaf lettuce in Norway. Lett Appl Microbiol 41(2):186-9.

Mattison K, Brassard J, Gagné M, Ward P, Houde A, Lessard L, Simard C, Shukla A, Pagotto F, Jones TH, Trottier Y. 2009. The feline calicivirus as a sample process control for the detection of food and waterborn RNA viruses. Int J Food Microbiol 132(1):73-7.

Mattison K, Harlow J, Morton V, Cook A, Pollari F, Bidawid S, Farber JM. 2010. Enteric viruses in ready-to-eat packaged leafy greens. Emerg Infect Dis 16(11):1815-7.

Mercanoglu TB, Halkman AK. 2011. Do leafy green vegetables and their ready-to-eat [RTE] salads carry a risk of foodborne pathogens?. Anaerobe 17(6):286-7.

Morales-Rayas R, Wolffs PFG, Griffiths MW. 2010. Simultaneous separation and detection of hepatitis A virus and norovirus in produce. Int J Food Microbiol 139(1-2):48-55.

Oliveira M, Usall J, Viñas I, Anguera M, Gatius F, Abadias M. 2010. Microbiological quality of fresh lettuce from lettuce from organic and conventional production. Food Microbiol 27(5):679-84

Patel MM, Widdowson MA, Glass RI, Akazawa K, Vinjé J, Parashar UD. 2008. Systematic literature review of role of noroviruses in sporadic gastroenteritis. Emerg Infect Dis 14(8):1224-31.

Patel MM, Hall AJ, Vinje J, Parashar UD. 2009. Noroviruses: a comprehensive review. J Clin Virol 44(1):1-8

Prado T, Silva DM, Guilayn WC, Rose TL, Gaspar AM, Miagostovich MP. 2011. Quantification and molecular characterization of enteric viruses detected in effluents from two hospital wastewater treatment plants. Water Research 45(3):1287-97.

Rajal VB, Mcswain BS, Thompson DE, Leutenegger CM, Wuertz S. 2007a. Molecular quantitative analysis of human viruses in California stormwater. Water Research 41(19):4287-98.

Rajal VB, Mcswain BS, Thompson DE, Leutenegger CM, Kidare BJ, Wuertz S. 2007b. Validation of hollow fiber ultrafiltration and real-time PCR using bacteriophage PP7 as surrogate for the quantification of viruses from water samples. Water Research 41(7):1411-22.

Sánchez G, Elizaquível P, Aznar R. 2012. A single method for recovery and concentration of enteric viruses and bacteria from fresh-cut vegetables. Int J Food Microbiol 152(1-2):9-13.

Santos TBA, Junqueira NSVCA, Pereira JL. 2010. Microrganismos indicadores em frutas e hortaliças minimamente processadas. Brazilian J Food Technol 13(2):141-6.

Scherer K, Johne R, Schrader C, Ellerbroek L, Schulenburg J, Klein G. 2010. Comparison of two extraction methods for viruses in food and application in a norovirus gastroenteriti outbreak. J Virol Methods 169(1):22-7.

Silva SRP, Verdin SEF, Pereira DC, Schatkoski AM, Rott MB, Corção G. 2007. Microbiological quality of minimally processed vegetables sold in Porto Alegre, Brazil. Brazilian J Microbiol 38(4):594-8.

Stals A, Baert L, Van coillie E, Uyttendaele M. 2011. Evaluation of a norovirus detection methodology for soft red fruits. Food Microbiol 28(1):52-8.

Tresseler JFM, Figueiredo EAT, Figuereido RW, Machado TF, Delfino CM, Sousa PHM 2009. Avaliação da qualidade microbiológica de hortaliças minimamente processadas. Ciência e agrotecnologia, Lavras 33:1722-7.

Uhrbrand K, Myrmel M, Maunula L, Vainio K, Trebbien R, Nørrung B, Schultz AC. 2010. Evaluation of a rapid method for recovery of norovirus and hepatitis A virus from oysters and blue mussels. J Virol Methods 169(1):70-8. 
Victoria M, Rigotto C, Moresco V, Corrêa AA, Kolesnikovas C, Leite JPG, Miagostovich MP, Barardi CRM. 2010. Assessment of norovirus contamination in environmental samples from Florianópolis City, Southern Brazil. J Appl Microbiol 109(1):231-8 Yin JL, Shackel NA, Zekry A, McGuinness PH, Richards C, Putten KV, McCaughan GW, Eri JM, Bishop GA. 2001. Real-time reverse transcriptase polymerase chain reaction (RT-PCR) for measurement of cytokine and growth factor mRNA expression with fluorogenic probes or SYBR Green I. Immunol Cell Biol 79(3):213-21.

Zheng DP, Ando T, Fankhauser RL, Beard RS, Glass RI, Monroe SS. 2006. Norovirus classification and proposed strain nomenclature. Virology 346(2):312-23. 